\title{
NOTES
}

\section{ENTRAPMENT AND DENIAL OF THE CRIME: A DEFENSE OF THE INCONSISTENCY RULE}

Although litigants in civil proceedings are permitted to argue inconsistent positions, ${ }^{1}$ most federal courts have not allowed inconsistent defenses in criminal cases. ${ }^{2}$ Concern over this so-called "inconsistency rule" in criminal cases most frequently arises with respect to the entrapment defense. Currently, the federal courts of appeals are split on the question whether a criminal defendant who wants to plead entrapment may also assert other defenses. ${ }^{3}$ The Supreme Court has declined to resolve the issue. ${ }^{4}$

After a brief discussion of the development of the entrapment defense, this note outlimes the four approaches that the federal courts of appeals have taken in addressing whether a criminal defendant may assert inconsistent defenses in an entrapment case. 5 The note advocates adherence to the imconsistency rule, but suggests that courts adopt a more precise definition of "inconsistency" in this context. 6 The proposed rule would prohibit a defendant from denying a crime and asserting entrapment. It would not, however, require a defendant to admit the crime as a prerequisite to an entrapment plea. A defendant could deny the crime or not testify at all and receive entrapment instructions if the government's case-in-chief establishes entrapment as a matter of law.

1. FED. R. CIV. P. 8(e)(2).

2. For discussion of the federal case law on inconsistent defenses in criminal cases, see infra notes 125-29 and accompanying text. text.

3. For discussion of the four varying approaches, see infra notes 26-124 and accompanying

4. Recent Supreme Court cases dealing with entrapment have focused on the nature of the entrapment defense and have not addressed the issue whether the defense requires admission of the crime. See Hampton v. United States, 425 U.S. 484 (1976) (entrapment defense unavailable to predisposed defendant); United States v. Russell, 411 U.S. 423 (1973) (fact that government agent supplied necessary ingredient for manufacture of illegal drugs does not establish entrapment where defendant's predisposition to commit crime is conceded).

5. See infra notes 26-124 and accompanying text.

6. See infra notes $141-214$ and accompanying text. 


\section{Development of the Entrapment Defense}

The United States Supreme Court first recognized the defense of entrapment in Sorrells v. United States. ${ }^{7}$ Charged with selling liquor to a prohibition agent, Sorrells argued at trial that he had been entrapped. ${ }^{8}$ The trial court rejected the defense, and the court of appeals affirmed. ${ }^{9}$ The Supreme Court reversed, finding that the evidence of entrapment was sufficient to go to the jury. ${ }^{10}$ Although it acknowledged that government agents may detect crime by affording opportunities for its commission, the Court stated that "[a] different question is presented when the criminal design originates with the officials of the government, and they implant in the mind of an innocent person the disposition to commit the alleged offense and induce its commission in order that they may prosecute."11

The Court held that the entrapment defense has two elements. First, the defendant must produce evidence that the offense "was committed at the instance of government officials."12 Second, once the defendant produces such evidence, the trial court must focus on the defendant's predisposition to commit the crime charged. The court should determine "whether the defendant is a person otherwise innocent whom the government is seeking to punish for an alleged offense which is the product of the creative activity of its own officials."13 The Supreme Court emphasized that entrapment was not an excuse for a guilty defendant; the entrapped mdividual is simply not guilty of committing a crime. ${ }^{14}$ The Court based its holding on statutory construction, asserting that Congress could not have intended to punish individuals for crimes that the government instigated. ${ }^{15}$

Justice Roberts, joined by Justices Brandeis and Stone, dissented in part and argued strongly for an alternative formulation of the defense that would focus on the behavior of the government agents, not the defendant's predisposition to coinmit the crime. ${ }^{16}$ The dissent objected to the artificiality of the majority's statutory construction analysis ${ }^{17}$ and argued that "courts must be closed to the trial of a crime instigated by the
7. 287 U.S. 435 (1932).
8. Id. at 438 .
9. Id. at $438-39$.
10. Id. at 441 .
11. Id. at 442 .
12. Id. at 451 .
13. Id.
14. Id. at 452 .
15. Id. at 448.
16. Id. at 454 (Roberts, J., dissenting in part).
17. Id. at 456 . 
government's own agents."18 In the dissent's view, the majority's emphasis on the predisposition of the defendant would cause prosecutors to introduce evidence of bad character or past offenses, in effect putting the accused on trial for previous acts. ${ }^{19}$

Since Sorrells, the Court has continued to be divided over the formulation of the entrapment defense. A majority still supports the subjective approach focusing on the predisposition of the defendant to commit the crime. ${ }^{20}$ And a vocal minority continues to advocate adopting the objective test proposed by Justice Roberts. ${ }^{21}$

Even if the entrapment defense fails, a majority of the Supreme Court has indicated that excessive governmental involvement in instigating criminal activity may give rise to a due process defense. ${ }^{22}$ For example, in a lower court case, United States v. Twigg, ${ }^{23}$ government agents supphed essential chemical ingredients and equipment and extensively aided the defendant in setting up an illegal drug laboratory. The defendant argued that the government had entrapped him; alternatively, he argued that the government's conduct violated due process. ${ }^{24}$ The United States Court of Appeals for the Third Circuit rejected the entrapment

18. Id. at 459 .

19. Id. at 458-59.

20. See United States v. Russell, 411 U.S. 423,436 (1973) (entrapment comes into play only when government actually implants the criminal design in the mind of the accused); Sherman v. United States, 356 U.S. 369, 376-77 (1958) (rejecting suggestion that Court adopt objective approach to entrapment advocated by Justice Roberts in Sorrells).

21. See Russell, 411 U.S. at 441 (Stewart, J., dissenting); Sherman, 356 U.S, at 380 (Frankfurter, J., concurring in the result).

The objective approach to entrapment focuses on the government's efforts to induce the crime. The formulation of the objective entrapment defense is set forth in the Model Penal Code: entrapment occurs when the government employs "methods of persuasion or inducement [that] create a substantial risk that such an offense will be committed by persons other than those who are ready to commit it." Model Penal CODE $\$ 2.13$ (1962).

A number of state legislatures have adopted the objective approach to entrapment. See ARK. Stat. ANN. § 41-209 (1977); Colo. REV. STAT. § 18-1-709 (1978); Haw. REV. Stat. § $702-$ 237(1)(b) (1976); N.H. REV. STAT. ANN. § 626:5 (1974); N.J. STAT. ANN. § 2C:2-12(a)(2) (West 1982); N.D. CENT. CODE § 12.1-05-11 (1985); 18 PA. CONS. STAT. ANN. $§ 313(a)$ (2) (Purdon 1983); Tex. Penal Code ANN. \$ 8.06(a) (Vernon 1974); Utah Code ANN. \$ 76-2-303(1) (1978). Other states have adopted the objective entrapment standard by judicial decision. See Grossman v. State, 457 P.2d 226, 229 (Alaska 1969); People v. Barraza, 23 Cal. 3d 675, 690, 591 P.2d 947, 955, 153 Cal. Rptr. 459, 467 (1979); State v. Mullen, 216 N.W.2d 375, 382 (Iowa 1974); People v. Turner, 390 Mich. 7, 22, 210 N.W.2d 336, 342 (1973); State v. Wilkins, 144 Vt. 22, 29, 473 A.2d 295, 298 (1983).

22. See Hampton v. United States, 425 U.S. 484, 493 (Powell, J., concurring in the judgment); id. at 497 (Brennan, J., dissenting).

23. 588 F.2d 373, 375-76 (3d Cir. 1978). It should be noted that while Twigg has not been overruled, later Third Circuit cases have limited it to its facts. See United States v. Beverly, 723 F.2d 11, 12 (3d Cir. 1983) (noting that Twigg has been limited by later Supreme Court and Third Circuit decisions); United States v. Jannotti, 673 F.2d 578, 608 (3d Cir.) (distinguishing Twigg), cert. denied, 457 U.S. 1106 (1982).

24. Twigg, 588 F.2d at 381-82. 
argument, but held that the government had abridged the defendant's due process rights. ${ }^{25}$ The court found no inconsistency in allowing the defendant to argue that he was entrapped and that government agents violated his due process rights.

\section{Federal Application of the Inconsistency Rule}

Since Sorrells, numerous cases have arisen in which the defendant has attempted to assert entrapment without conceding commission of the crime charged. The federal courts of appeals have disagreed on the appropriate treatment of such cases, and four distinct approaches have evolved. The Third, Sixth, and Seventh Circuits require a defendant to admit commission of the crime as a prerequisite to asserting the entrapment defense. ${ }^{26}$ The First, Second, Fourth, and Tenth Circuits allow a defendant to remain silent and assert entrapinent, but do not allow a defendant who denies commission of the crime to plead entrapment. ${ }^{27}$ The Fifth and Eleventh Circuits have held that a defendant who denies the intent element of the crime inay plead entrapinent, but a defendant who denies the acts charged may not. ${ }^{28}$ Finally, the Ninth Circuit and the District of Columbia Circuit allow defendants to assert defenses regardless of inconsistency. ${ }^{29}$

\section{A. Courts Requiring Admission of All Elements of the Crime.}

The Third, ${ }^{30}$ Sixth, ${ }^{31}$ and Seventh Circuits ${ }^{32}$ adhere to the rule that in order to plead entrapment, the defendant must first admit commission

25. Id. at 376, 380-81. A plurality of the Supreme Court has indicated that the defendant who does not wish to raise the entrapment defense because of its predisposition aspect may rely solely on the due process defense. See Hampton v. United States, 425 U.S. 484, 489 (1976) (plurality opinion).

26. See infra notes 30-36 and accompanying text.

27. See infra notes 37-62 and accompanying text.

28. See infra notes 63-109 and accompanying text.

29. See infra notes 110-24 and accompanying text.

30. See United States v. Hill, 655 F.2d 512, 514 (3d Cir. 1981) (entrapment defense requires admission of all elements of crime charged); United States v. Watson, 489 F.2d 504, 507 (3d Cir. 1973) (defendant not entitled to entrapment instructions on charges he did not admit). But see United States v. Jannotti, 501 F. Supp. 1182, 1201 (E.D. Pa. 1980) (stating that defendant should be allowed to deny mental element and plead entrapment), rev'd, 673 F.2d 578 (3d Cir.), cert. denied, 457 U.S. 1106 (1982).

31. See infra notes 33-36 and accompanying text; see also United States v. Whitley, 734 F.2d 1129, 1139 (6th Cir. 1984) (admission of every element of crime charged is a necessary prerequisite to entrapment plea); United States v. Ranzoni, 732 F.2d 555, 560 (6th Cir.) (same), cert. denied, 469 U.S. 916 (1984). But see United States v. Baker, 373 F.2d 28, 30 (6th Cir. 1967) (denial of intent does not preclude entrapment defense).

32. See United States v. Liparota, 735 F.2d 1044, 1048 (7th Cir. 1984) (defendant must admit commission of offense in order to assert entrapment), rev'd on other grounds, 471 U.S. 419 (1985); United States v. Johnston, 426 F.2d 112, 114 (7th Cir. 1970) (same). 
of the crime charged. The rationale behind this rule is that a defendant who has not committed a crime cannot have been the victim of entrapment. Thus, until the fact of the crime has been established, entrapment does not become an issue.

For example, in United States v. Bryant, ${ }^{33}$ Bryant was convicted for the purchase of illegally obtained fox pelts. On appeal, Bryant objected to the trial court's denial of his instruction on entrapment. ${ }^{34}$ The United States Court of Appeals for the Sixth Circuit upheld the action of the trial judge, noting that "[w]hen carefully questioned by the court on this issue, [Bryant] repeatedly refused to admit to all elements of the crime." 35 The court concluded that Bryant's failure to concede all elements of the crime precluded him from raising the entrapment defense. ${ }^{36}$

\section{B. Courts Requiring Silence as to the Elements of the Crime.}

The First, ${ }^{37}$ Second, ${ }^{38}$ Fourth, ${ }^{39}$ and Tenth Circuits ${ }^{40}$ have held that a defendant does not have to admit committing the crime in order to plead entrapment, but the defendant may not deny the crime and plead entrapment. ${ }^{41}$ These courts have concluded that the defendant's silence as to the elements of the crime is not inconsistent with an assertion of the entrapment defense. ${ }^{42}$ The courts have expressed the concern that requiring the defendant to admit committing the crime as a prerequisite to raising the entrapment defense may violate the defendant's fifth amendment rights against compelled self-incrimination. ${ }^{43}$

33. 716 F.2d 1091, 1092 (6th Cir. 1983), cert. denied, 465 U.S. 1009 (1984).

34. Id. at 1094.

35. Id.

36. $I d$.

37. See infra notes $44-51$ and accompanying text; see also United States v. Caron, 588 F.2d 851, 852 (1st Cir. 1978) (defendant could plead entrapment where he had admitted sufficient facts to warrant finding him guilty).

38. See infra notes $52-58$ and accompanying text.

39. See infra notes $59-62$ and accompanying text.

40. See Munroe v. United States, 424 F.2d 243, 244 (10th Cir. 1970) ("The law is well settled in this circuit that if the defendant denies the commission of the crime charged, the defense of entrapment is not available to him.").

41. Although the Eighth Circuit has not addressed the issue, it has indicated in dictum that it would apply the same rule. See United States v. Kutrip, 670 F.2d 870, 876 (8th Cir. 1982) (trial court's refusal to instruct on entrapment because defendant relied on necessity defense was not plain error); Kibby v. United States, 372 F.2d 598, 601 (8th Cir.) (declining to decide whether defendant can claim entrapment without admitting guilt), cert. denied, 387 U.S. 931 (1967); Ware v. United States, 259 F.2d 442, 445 (8th Cir. 1958) (noting that since defendant denied crime, claim of entrapment would be inappropriate).

42. See, e.g., United States v. Annese, 631 F.2d 1041, 1046 (1st Cir. 1980) (discussed infra notes 44-51 and accompanying text).

43. See infra note 51 and accompanying text. 
In United States v. Annese, ${ }^{44}$ the United States Court of Appeals for the First Circuit addressed the issue whether the defendant could refuse to testify yet plead entrapment. In Annese, the trial court ruled that the defendant was not entitled to instructions on entrapment unless he testified. ${ }^{45}$ The defendant testified, was subjected to vigorous cross-examination, ${ }^{46}$ and was convicted. ${ }^{47}$ On appeal, the First Circuit held that it was error to require the defendant to testify as a precondition to using the entrapment defense. ${ }^{48}$ While noting that under circuit precedent a defendant who denies imvolvement im the crime may not plead entrapment, the court held that a defendant may refuse to testify without waiving his right to the entrapment defense. ${ }^{49}$ The court pointed out that "[w]hile the success of a defendant in convincing a jury that he was entrapped may be reduced by his failure to testify, that is a choice that he has a right to make free of any compulsion whatsoever." 50 The court reasoned that requiring a defendant to admit the crime as a precondition to pleading entrapment "would raise a serious fifth amendment question." 51

The United States Court of Appeals for the Second Circuit has developed a similar rule. In United States $v$. Valencia, ${ }^{52}$ the court held that a nontestifying defendant could assert entrapment as a defense. The defendant was entitled to instructions on entrapment "since he did not take the stand to deny personally his participation in the transaction and did not affirmatively introduce any other evidence that he was not involved." 53 The court reserved the question whether entrapment would be available to a defendant who testified that he was not involved in the crime or who presented alibi witnesses. ${ }^{54}$

In United States v. Mayo, ${ }^{55}$ the Second Circuit addressed part of the question it had left open in Valencia: whether a defendant who testifies that he did not participate in the crime could also plead entrapment. The court held that denial of the acts charged precluded the defendant from asserting entrapment. ${ }^{56}$ The Mayo court, however, emphasized that it was not deciding whether a defendant who admitted the acts charged but
44. 631 F.2d 1041 (1st Cir. 1980).
45. Id. at 1045 .
46. Id. at 1047 .
47. Id. at 1042 .
48. Id. at 1045 .
49. Id. at 1047 .
50. Id.
51. Id.
52. 645 F.2d 1158 (2d Cir. 1980).
53. Id. at 1172 .
54. Id.
55. 705 F.2d 62 (2d Cir. 1983).
56. Id. at 72-73. 
offered "an explanation of his conduct that was consistent with his theory of entrapment" would be entitled to both defenses. ${ }^{37}$ This language from Mayo indicates that the Second Circuit may be willing to consider adopting the more flexible rule followed in the Fifth Circuit, which allows a defendant to deny the intent element of the crime and assert entrapment. 58

In United States v. Dorta, ${ }^{59}$ the United States Court of Appeals for the Fourth Circuit rejected a prior circuit decision that allowed the assertion of inconsistent defenses ${ }^{60}$ and held that a defendant could not deny the crime and assert entrapment. The court noted that the rule against inconsistent defenses has been adopted by the majority of the federal courts of appeals ${ }^{61}$ and concluded that the rule was justified "in the interest of protecting the integrity and the truth-finding function of our criminal trials."62

\section{Courts Allowing Defendant to Deny Intent.}

The Fifth Circuit ${ }^{63}$ and the Eleventh Circuit ${ }^{64}$ currently allow a defendant to plead entrapment so long as he does not deny the acts charged. The defendant may, however, deny the intent element of the crime or simply not admit either act or intent.

In Henderson v. United States, ${ }^{65}$ the United States Court of Appeals for the Fifth Circuit demonstrated its willingness to take a flexible approach to the issue of inconsistent defenses. According to the court, the goal of a trial is to determine the truth, and inconsistent defenses should be permitted when they will be helpful in arriving at the truth. ${ }^{66}$ The degree to which permitting inconsistent defenses is helpful in determining the truth, however, depends on the degree of inconsistency. ${ }^{67}$ The court concluded that in certain cases proof of entrapment will "be so contrary ... to proof that the defendant is . . . not guilty [of the crime] ... that the proof of the one necessarily disproves the other." 68

In Sears v. United States, ${ }^{69}$ the Fifth Circuit indicated that the de-

57. Id. at 73 .

58. For a discussion of the Fifth Circuit rule, see infra notes 65-106 and accompanying text.

59. 783 F.2d 1179 (4th Cir.), cert. denied, 106 S. Ct. 3274 (1986).

60. Id. at 1181 (citing Crisp v. United States, 262 F.2d 68, 70 (4th Cir. 1958)).

61. Id.

62. Id. at 1181-82.

63. See infra notes $65-106$ and accompanying text.

64. See infra notes 107-09 and accompanying text.

65. 237 F.2d 169 (5th Cir. 1956).

66. Id. at 172 .

67. Id.

68. Id. at 173 .

69. 343 F.2d 139, 142-43 (5th Cir. 1965). 
fendant could raise the entrapment defense even if the defendant denied committing the crime charged, provided the government's evidence introduced the entrapment issue. The court stated that "[w]e do not think it is impermissibly inconsistent for a defendant to deny the acts charged, yet urge the court on motion for acquittal that the government's own evidence establishes entrapment as a matter of law."70 Sears goes farther than Henderson did, since it permits a defendant to deny all elements of the crime and still rely on entrapment.

For a period of time, two lines of Fifth Circuit cases conflicted over whether a defendant could deny the intent element of the crime and also present evidence on entrapment. One line of cases held that it was not impermissibly inconsistent for a defendant to argue that he lacked criminal intent but also argue entrapment as an alternative defense, ${ }^{71}$ while another lime of cases reached the opposite conclusion. ${ }^{72}$

The Fifth Circuit recoguized and resolved the conflict between these two lines of cases in United States v. Henry (Henry I). ${ }^{73}$ Henry I involved a prosecution for illegally prescribing drugs. ${ }^{74}$ Henry admitted at trial that he prescribed the drugs, but demied that he intended to prescribe them for nonmedicinal purposes. ${ }^{75}$ The trial court refused to instruct the jury on entrapment, relying on the cases holding that a defendant may not plead both lack of intent and entrapment. ${ }^{76}$

On appeal, the Fifth Circuit acknowledged the conflicting circuit precedent on whether the entrapment defense is available to a defendant

70. Id. at 143.

71. An example is United States v. Greenfield, 554 F.2d 179 (5th Cir. 1977), which involved a prosecution for illegally prescribing drugs. The trial court refused to instruct on entrapment because of Greenfield's testimony that he had prescribed the drugs for a legitimate medical purpose. Id. at 181. The Fifth Circuit reversed, holding that Greenfield could argue "that he did not knowingly dispense the drugs without a legitimate medical purpose or, alternatively, he may argue that to the extent that he may have prescribed without a legitimate medical purpose, he was not predisposed to do so." Id. at 183. The court found that "the entrapment defense is not so inconsistent with the defense of lack of intent under the circumstances of this case as to preclude the alternative defenses." Id. See also United States v. Garrett, 716 F.2d 257, 271 (5th Cir. 1983) (defense of lack of intent not inconsistent with entrapment defense), cert. denied, 466 U.S. 937 (1984).

72. See United States v. Nicoll, 664 F.2d 1308 (5th Cir.), cert. denied, 457 U.S. 1118 (1982). At trial, Nicoll claimed that he had participated in the charged drug conspiracy only to "lead on" the DEA in the hope of obtaining some cocaine for his personal use. Id. at 1314. On appeal he urged the court to find that he had been entrapped as a matter of law. The court held that Nicoll had failed to establish the entrapment issue at trial because he relied on a mens rea defense. As a result, the court refused to consider entrapment on appeal. Id. See also McCarty v. United States, 379 F.2d 285, 286 (5th Cir.) (defendant who denied intent element of the crime not entitled to entrapment instructions), cert. denied, 389 U.S. 929 (1967).

73. 727 F.2d 1373 (5th Cir.), rev'd en banc, 749 F.2d 203 (5th Cir. 1984).

74. Id. at 1374 .

75. Id.

76. Id. 
who admits the acts charged but denies the intent element of the crime. ${ }^{77}$ The court noted that while Henry denied intent to commit a criminal act, his reliance on the entrapment defense constituted an assertion that he had criminal intent but that the government agent had implanted it. ${ }^{78}$ The court reasoned that "[i]f there [are] degrees of inconsistency ... this seems an instance of a high one: not only that a culpable intent both did and did not exist in the same person at the same time, but that if it did it had a particular cause."79 The court found "no significant force in the reasoning by which an exception is made for the eleinent of intent alone from the concessions required to raise the entrapment defense" 80 and concluded that the trial court had acted correctly in refusing to instruct on entrapment. . $^{81}$

On rehearing en banc, however, the Fifth Circuit voted 8-6 to reverse the panel's decision. ${ }^{82}$ The en banc court, in Henry II, first noted that the panel had erroneously characterized the entrapment defense as "being in the nature of a confession and avoidance." 83 Under that analysis the panel had concluded that the issue of entrapment, which concerns the origin of the defendant's criminal intent, becomes relevant only after the defendant has conceded that he committed the criminal act with the requisite intent. ${ }^{84}$ The Henry II majority rejected the panel's formulation of entrapment, findimg it to be inconsistent with Supreme Court decisions outliming the defense. ${ }^{85}$ According to the Henry II court, the entrapment defense does not function as an excuse or justification for a guilty defendant; the entrapment victim is simply not guilty. ${ }^{86}$ Thus, conceding guilt cannot be a prerequisite to an entrapment plea. Instead, a nontestifying defendant "may rest upon his not guilty plea and ask the jury to evaluate all of the evidence in the case relevant to a guilty or not guilty verdict, including evidence that, because of entrapment, he did not have the requisite criminal intent." 87

The Henry II majority next addressed the question "whether a different rule should apply when (as here) a defendant elects to testify to his personal belief that he acted without criminal intent." 88 Noting the
77. Id. at 1374-76.
78. Id. at 1374 .
79. Id. at 1375 .
80. Id. at 1377 .
81. Id.
82. United States v. Henry, 749 F.2d 203, 214 (5th Cir. 1984) (en banc).
83. Id. at 207.
84. Id.
85. Id.
86. Id. at 210 .
87. Id. at 211.
88. Id. 
"amorphous and subjective" 89 nature of the intent element of a crime, the court reasoned that it was possible for the defendant and the jury to disagree over whether the defendant's intent was criminal at the time the act charged was committed. ${ }^{90}$ Consequently, the court held that a twostep inquiry was appropriate in situations where the defendant has denied the intent element but also requests instructions on entrapment. First, the jury should determine whether the defendant has committed a crime by assessing the evidence relevant to criminal intent. ${ }^{91}$ If the jury concludes that the defendant did act with criminal intent, the jury must then decide whether that intent originated in the defendant or was implanted by the government.92

In its analysis, the Henry II majority rehed heavily on the "degree of inconsistency" test outlined in United States $v$. Henderson. ${ }^{93}$ The court noted that entrapinent focuses on the defendant's predisposition and concluded that the evidence that the defendant could produce to negate an inference of criminal intent would also tend to show absence of predisposition. ${ }^{94}$ Thus, the Henry II inajority concluded that it is

not too inconsistent for a defendant to testify that he did not have the criminal intent required for conviction and then, through his lawyer's argument and the court's instruction on the law, to urge the jury, in the event it rejects his personal view concerning intent, to find that the evidence requires acquittal on the basis of the entrapment doctrine. ${ }^{95}$

Six judges dissented in Henry II. ${ }^{96}$ Although it admitted that the panel in Henry $I$ was incorrect in its characterization of entrapment as being in the nature of confession and avoidance, ${ }^{97}$ the dissent adhered to the panel's conclusion. In the dissent's view, the defendant should not be permitted "to swear that he had no criminal intent and in the saine breath to argue that he had one that did not originate with him."98 The dissent saw no significant difference between requiring a testifying defendant to concede cominission of the act charged in order to plead entrapment and requiring concession of criminal intent. ${ }^{99}$ The dissent also found fault with the majority's characterization of intent as "amorphous and subjective," coinmenting that Henry swore under oath that he acted

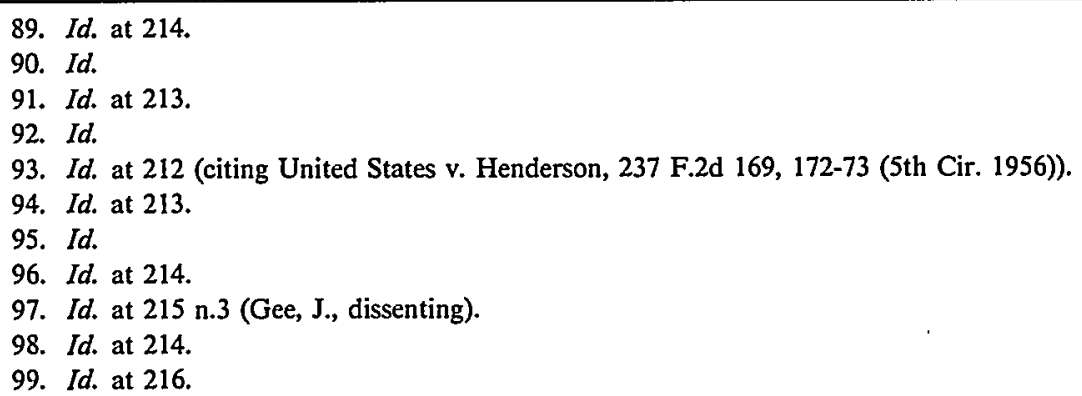


without criminal intent: "There was nothing amorphous about Henry's testimony, and, in Henry's own mind, nothing anorphous about his intent." 100 The dissent concluded that "in a proceeding so serious as a criminal trial" it should be impermissible for a defendant to "take the stand, solemnly swear to one thing, argue the contrary of his sworn testimony, and be acquitted on the latter basis." 101

In the aftermath of Henry II, a question may arise as to the continued viability of the rule formulated in Sears v. United States, ${ }^{102}$ which allows a defendant to deny the crime and plead entrapment if the government's evidence raises the entrapment issue. ${ }^{103}$ Henry II indicates that a defendant may not deny the acts charged and obtain instructions on entrapment, even when the defendant asserts that the government's evidence establishes entrapment as a matter of law. ${ }^{104}$ In Sears, however, the court allowed just such a combination of defenses. ${ }^{105}$ The Henry II majority apparently overlooked this conflict because it cited Sears approvingly. ${ }^{106}$ Although Henry II conflicts with Sears, Sears has not been expressly overruled. Thus, it is unclear how the Fifth Circuit will resolve the issue raised in Sears.

The United States Court of Appeals for the Eleventh Circuit still follows the Sears rule. In United States v. Haimowitz, ${ }^{107}$ the court held that a defendant who pleads entrapment may not deny commission of the acts charged unless the government's case-in-chief "injects substantial evidence of entrapinent into the case."108 Since the Fifth Circuit decided Henry II after the Eleventh Circuit was created, its holding is not binding on the Eleventh Circuit. It is unclear as yet how the Eleventh Circuit will resolve the pre-Henry conflict in Fifth Circuit precedent regarding the availability of the entrapment defense to a defendant who denies the intent element of the crime. ${ }^{109}$

D. Courts Allowing Inconsistent Defenses.

Courts in the Ninth Circuit ${ }^{10}$ and the District of Columbia Cir-

100. $I d$.

101. Id.

102. 343 F.2d 139 (5th Cir. 1965).

103. Id. at 143 .

104. Henry II, 749 F.2d at 205.

105. Sears, 343 F.2d at 143.

106. Henry II, 749 F.2d at 206 n.1.

107. 725 F.2d 1561 (11th Cir.), cert. denied, 469 U.S. 1072 (1984).

108. Id. at $1573-74$.

109. See United States v. Smith, 757 F.2d 1161, 1169 (11th Cir. 1985) (declining to resolve the conflicting Fifth Circuit precedent).

110. See infra notes $113-20$ and accompanying text. 
cuit $^{111}$ allow defendants to assert inconsistent defenses. The rationale given for this rule is that a criminal defendant "should be accorded every reasonable protection in defending himself against governmental prosecution." 112

In Eastman v. United States, ${ }^{113}$ the United States Court of Appeals for the Ninth Circuit refused to permit a plea of entrapment where the defendant had not conceded coininission of the crine. In United States $v$. Demma, ${ }^{114}$ however, the Nimth Circuit sitting en banc abandoned that position and held that defendants could assert inconsistent defenses.

The Demma court attacked the theoretical basis of the Eastman rule on several grounds. First, the court found that requiring concession of the crime as a prerequisite to an entrapment plea conflicted with the Supreme Court's holding in Sorrells that entrapment was raised by a not guilty plea. ${ }^{115}$ Second, the court held that even assuming the validity of the inconsistency theory on which the Eastman rule was based, the rule was overly broad. True inconsistency, the court argued, arises only when the defendant himself asserts two defenses that cannot both be accepted by the jury. ${ }^{116}$ The Eastman rule, however, would preclude the defendant from denying the crime and pleading entrapinent even when the government's evidence, not the defendant's, introduces the entrapment issue. ${ }^{117}$ The court went on to reject the inconsistency theory itself, asserting that "[i]t is well established that a defendant in a criminal prosecution may assert imconsistent defenses." 118 The court concluded that there was no justification for making an exception to the rule allowing

111. See infra notes 121-24 and accompanying text.

112. United States v. Demma, 523 F.2d 981, 985 (9th Cir. 1975).

113. 212 F.2d 320, 322 (9th Cir. 1954).

114. 523 F.2d 981, 982 (9th Cir. 1975) (en banc).

115. Id. at 983 .

116. Id. at 984 .

117. Id.

118. Id. at 985. As authority, the Demma court cited a number of cases. The first, United States v. Harrell, 436 F.2d 606 (5th Cir. 1970), held that a defendant who denied participation in a criminal conspiracy was entitled to instructions on entrapment where he argued that the government's evidence established entrapment as a matter of law. Id. at 611-12. These defenses are not truly inconsistent. See infra notes 155-57 and accompanying text. Thus, Harrell does not support the proposition that inconsistent defenses are appropriate in a criminal case.

The Demma court also relied on United States v. Harbin, 377 F.2d 78, 80 (4th Cir. 1967) ("inconsistent defenses may of course be made" in a criminal case). The Fourth Circuit, however, has recently rejected the rationale expressed in Harbin, holding that the entrapment defense may not be asserted by a criminal defendant who denies committing the crime. See United States v. Dorta, 783 F.2d 1179, 1181 (4th Cir.), cert. denied, 106 S. Ct. 3274 (1986).

Finally, the court cited a number of decisions by the Court of Appeals for the District of Columbia Circuit and one by a California state court. Both these jurisdictions allow the assertion of inconsistent defenses by criminal defendants. See infra notes 121-24, and accompanying text; see also People v. Perez, 62 Cal.2d 769, 401 P.2d 934, 44 Cal. Rptr. 326 (1965). 
inconsistent defenses when one of the defenses is entrapment. ${ }^{19}$ Finally, although the Demma court specifically stated that it was not basing its holding on constitutional grounds, it argued that "[c]ontinued adherence to Eastman would have generated serious constitutional problems by conditioning the assertion of a defense on the defendant's yielding his presumption of innocence, his right to remain silent, and his right to have the Government prove the elements of the crime beyond a reasonable doubt." 120

The United States Court of Appeals for the District of Columbia Circuit also allows criminal defendants to assert defenses regardless of their inconsistency, ${ }^{121}$ but does not view entrapment as inconsistent with other defenses, ${ }^{122}$ at least when evidence of entrapment is introduced by the government's witnesses. In Hansford $v$. United States, ${ }^{123}$ the court explained that "[i]t was consistent with defendant's denial of the transaction to urge that if the jury believed it did occur the government's evidence as to how it occurred indicated entrapment." ${ }^{124}$

\section{Factors Contributing to the Disagreement}

Three major factors contribute to the variation in the approaches the federal courts of appeals have adopted regarding the assertion of entrapment and inconsistent defenses. First, there are differing views among the circuits about the assertion of inconsistent defenses in criminal cases in general. The Ninth Circuit and the District of Columbia Circuit, which both follow the rule that a defendant may plead entrapment and deny the crime, also both allow assertion of inconsistent defenses in nonentrapment cases. ${ }^{125}$ Reasoning that there is no justification for making an exception when entrapment is one of the defenses raised, these courts allow assertion of any combination of defenses regardless of consistency. ${ }^{126}$

The other ten circuits, all of which restrict a defendant's ability to plead entrapment and other defenses, do not have a clear general rule regarding inconsistent defenses in criminal cases. Few, if any, cases from these circuits have addressed the inconsistency issue outside the context

119. Demma, 523 F.2d at 985.

120. Id. at 986.

121. See, e.g., Whittaker v. United States, 281 F.2d 631, 632 (D.C. Cir. 1960) (inconsistent defenses may be interposed in criminal cases).

122. See Hansford v. United States, 303 F.2d 219, 221 (D.C. Cir. 1962).

123. 303 F.2d 219 (D.C. Cir. 1962).

124. Id. at 221.

125. See United States v. Stern, 519 F.2d 521, 525 (9th Cir.), cert. denied, 423 U.S. 1033 (1975); Whittaker v. United States, 281 F.2d 631, 632 (D.C. Cir. 1960).

126. See, e.g., United States v. Demma, 523 F.2d 981, 985 (9th Cir. 1975). 
of entrapment. ${ }^{127}$ Nor do the entrapment cases give any guidance on the question whether inconsistent defenses are available in criminal cases generally. One Eleventh Circuit case, United States v. Smith, ${ }^{128}$ stated that the rule prohibiting assertion of entrapment and other defenses is an exception, for "defendants may assert inconsistent defenses in other contexts." 129 The court, however, cited no authority. Thus, among the courts of appeals that have applied the inconsistency rule in cases involving pleas of entrapment, there appears to be no precedent either supporting or denying the existence of an inconsistency rule in criminal cases outside the entrapment context.

Second, the variation in approaches reflects differing interpretations of the nature and function of the entrapment defense. There is disagreement, for exainple, over whether a defendant can be entrapped into committing noncriminal acts. The United States Court of Appeals for the Ninth Circuit in United States v. Demma ${ }^{130}$ stated that entrapment focused on whether the government induced the acts charged, regardless of whether it also induced criminal intent. It followed that denial of criminal intent was not inconsistent with an entrapinent plea; a defendant could argue that the government entrapped him into committing acts that were not criminal because he lacked intent. ${ }^{131}$ In contrast, the dissent in Henry II emphasized that the focus of entrapment was on the origin of the defendant's criminal imtent. ${ }^{132}$ A jury could not, in the Henry II dissent's view, conclude both that the defendant lacked the requisite intent and that he had been entrapped. ${ }^{133}$

This disagreement can be attributed in part to the Sorrells decision. At tines the Court uses language suggesting that government instigation of the acts charged is the essence of entrapment, ${ }^{134}$ while at other times the Court defines entrapment as the implantation by governinent agents

127. The author has not discovered any cases from these circuits that consider the inconsistency rule where entrapment was not one of the defenses raised.

Examples of nonentrapment cases where inconsistent defenses were allowed include Johnson v. United States, 426 F.2d 651, 656 (D.C. Cir. 1970) (en banc) (denial of sexual intercourse and claim of consent), cert. dismissed, 401 U.S. 846 (1971); and Whittaker v. United States, 281 F.2d 631, 632 (D.C. Cir. 1960) (denial of underlying acts and claim of insanity).

128. 757 F.2d 1161 (11th Cir. 1985).

129. Id. at 1167.

130. 523 F.2d 981, 984 (9th Cir. 1975).

131. Id.

132. Henry II, 749 F.2d at 214 (Gee, J., dissenting).

133. Id.

134. Sorrells, 287 U.S. at 448 (entrapment defined as "instigation by government officials of an act on the part of persons otherwise innocent in order to lure them to its commission and to punish them"). 
of criminal intent in the mind of the accused. 135

The function of the entrapment defense has also been the subject of disagreement. The Demma majority asserted that "[t]he primary function of entrapment is to safeguard the integrity of the law enforcement and prosecution process," 136 thereby justifying a rule that allowed a defendant to argue entrapment whenever there was evidence of unacceptable government activity in inducing crime. Justice Roberts, however, who proposed this interpretation of the purpose of the entrapment defense in his dissenting opimion in Sorrells, noted that the Sorrells majority implicitly rejected this view of entrapment as a "fundamental rule of public policy."137 Post-Sorrells Supreme Court decisions indicate that due process analysis, ratler thian the entrapment defense, is appropriate to guard against undue government involvement in the creation of crime. ${ }^{138}$

Finally, the courts differ as to wlien defenses should be considered mconsistent. Some courts argue that the inconsistency rule should apply and bar tlie defendant from presenting inconsistent defenses only when the defendant presents evidence in support of more than one defense. ${ }^{139}$ Otlier courts would extend the inconsistency rule wlien the defendant presents evidence on one defense but allows his counsel to assert other defenses during argument. ${ }^{140}$

\section{IN DEFENSE OF THE INCONSISTENCY RULE}

An evaluation of the continued desirability of the inconsistency rule must focus on balancing society's interest in the trutli-finding function of criminal trials against the need to protect the interests of criminal de-

135. Id. at 442 (criminal design originates with government and is implanted in mind of accused).

136. Demma, 523 F.2d at 985.

137. Sorrells, 287 U.S. at 457 (Roberts, J., dissenting in part).

138. See supra notes $22-25$ and accompanying text.

139. See, e.g., United States v. Haimowitz, 725 F.2d 1561, 1573-74 (11th Cir. 1984) (defendant may deny crime and raise entrapment defense where government's case-in-chief provides evidence of entrapment); United States v. Valencia, 645 F.2d 1158, 1172 (2d Cir. 1980) (defendant can assert dual defenses of noninvolvement and entrapment "since he did not take the stand to deny personally his participation in the transaction and did not affirmatively introduce any other evidence that he was not involved"); Sears v. United States, 343 F.2d 139, 143 (5th Cir. 1965) (not impermissibly inconsistent for defendant to deny acts charged and argue that government's evidence establishes entrapment as a matter of law).

140. See, e.g., United States v. Watson, 489 F.2d 504, 507 (3d Cir. 1973) (defendant who did not admit commission of crime charged was not entitled to raise entrapment defense). See supra notes 30-36 and accompanying text. 
fendants. ${ }^{141}$ This balance will necessarily be different than the balance of interests in a civil proceeding. First, because a criminal act is a wrong against society, society has an interest in determining guilt which is not present in civil proceedings. ${ }^{142}$ Second, a criminal defendant is entitled to additional constitutional protections when the government's investigative and prosecutorial forces are arrayed against him. ${ }^{143}$ The optimum balance between society's interest and the defendant's interest can be accoinplished by adopting an inconsistency rule that prohibits the criminal defendant from arguing positions that are mutually exclusive, while requiring the government to prove every element of the charges against the defendant.

This note's proposed rule looks to the basic purpose of the inconsistency rule to redefine the rule with three major exceptions. The basic purpose of the current inconsistency rule is to preserve the truth-seeking function of criminal trials. ${ }^{144}$ Thus, under the proposed inconsistency rule the courts should not permit a defendant simultaneously to deny the acts charged or the intent eleinent of the crime and claim that he was entrapped. The positions are mutually exclusive. ${ }^{145}$ But, im order to fully protect the defendant from the risk that government informants will commit perjury, the courts must also instruct on entrapment when the government's evidence, standing alone, presents the entrapment issue, even if the defendant demies committing the crime charged. ${ }^{146}$ Second, the courts should not interpret the rule to require affirmative admission of the crime as a prerequisite to an entrapment defense. ${ }^{147}$ Thus, courts should not bar a nontestifying defendant from pleading entrapment if it is raised by the evidence.

141. See Henderson v. United States, 237 F.2d 169, 172 (5th Cir. 1956) (goal of trials is to arrive at the truth; degree of inconsistency should be considered in determining whether inconsistent positions will help or hinder search for truth).

142. See, e.g., Thompson v. Bannan, 298 F.2d 611, 614 (6th Cir.) ("The public has an interest in criminal prosecutions and they are made for the protection of the citizens of a state and in order that there may be orderly government under law."), cert. denied, 370 U.S. 957 (1962).

143. For example, the sixth amendment right to counsel comes into play in a criminal prosecution. See, e.g., Moran v. Burbine, 106 S. Ct. 1135, 1146 (1986) (purpose of sixth amendment right to counsel is to assure that defendant receives legal assistance when facing society's prosecutorial forces). The fifth amendment's protection against compelled self-incrimination is also applicable. See id. at 1140 (compulsion inherent in custodial interrogation led Court to establish Miranda procedures to protect the accused's privilege against self-incrimination).

144. See United States v. Dorta, 783 F.2d 1179, 1181-82 (4th Cir.) (purpose of inconsistency rule in entrapment cases is to protect integrity and truth-finding function of criminal trials), cert. denicd. 106 S. Ct. 3274 (1986).

145. See infra note 206 and accompanying text.

146. See infra notes $155-57$ and accompanying text.

147. See infra notes 158-61 and accompanying text. 
The proposed inconsistency rule has many advantages. It protects the defendant when the government's evidence standing alone establishes entrapment, ${ }^{148}$ avoids the constitutional problems of requiring a defendant to plead guilty, ${ }^{149}$ and prohibits the affirmative presentation of mutually exclusive defenses. ${ }^{150}$ Prohibiting the defendant from presenting mutually exclusive defenses helps to prevent perjury, ${ }^{151}$ jury confusion, ${ }^{152}$ and an erosion of the defendant's credibility. ${ }^{153}$ Finally, public policy arguments that favor allowing inconsistent defenses as a means to protect against overzealous government agents fail to recognize that the federal courts apply a subjective entrapment test and that the due process defense provides protection from overzealous government agents. ${ }^{154}$

The proposed rule protects a defendant by requiring instructions on entrapment if the government's evidence, standing alone, establishes the defense. As the Umited States Court of Appeals for the District of Columbia Circuit in Hansford v. United States ${ }^{155}$ pointed out, the defendant who denies the crime and argues that the government's evidence shows entrapment as a matter of law is not really presenting inconsistent defenses. ${ }^{156}$ The defendant is, in effect, arguing that the government's contention that he committed a crime is false, but that even if it were true, he would not be guilty because of entrapment. ${ }^{157}$ The defendant's two arguments are not mutually exclusive; it may be true both that the defendant did not commit the crime and that the government's case-in-chief established entrapment. Denying instructions on entrapment in this situation would be unfair. It would allow the jury to convict the defendant in reliance on the government's evidence when that same evidence establishes entrapment. In such a situation, the judge should instruct the jury on entrapment but not allow the defendant to present any evidence sup-

148. See infra notes $155-57$ and accompanying text.

149. See infra notes 158-61 and accompanying text.

150. See infra note 162 and accompanying text.

151. See infra notes $163-92$ and accompanying text.

152. See infra notes $195-97$ and accompanying text.

153. See infra notes $198-99$ and accompanying text.

154. See infra notes 200-14 and accompanying text.

155. 303 F.2d 219, 221 (D.C. Cir. 1962).

156. See also Sears v. United States, 343 F.2d 139, 143 (5th Cir. 1965) (denial of crime and assertion that government's evidence establishes entrapment as a matter of law are not inconsistent positions).

157. Government informers frequently have a substantial motive both to entrap the defendant and to commit perjury. See Groot, The Serpent Beguiled Me and I (Without Scientcr) Did EatDenial of Crime and the Entrapment Defense, 1973 U. IL... L.F. 254, 263 \& n.40.

Groot notes that frequently the informant is under indictment for the same crime that he is attempting to induce others to commit or is being paid by the government on a per conviction basis. Id. In either event, the informant has much to gain (dismissal of a pending indictment against him or the contingent fee) from entrapping the accused and then denying that entrapment occurred. $I d$. 
porting the entrapment claim, since that would be inconsistent with denial of the crime.

The proposed inconsistency rule also avoids the constitutional problems that arise when courts require a defendant to admit the crime in order to plead entrapment. Both courts ${ }^{158}$ and commentators ${ }^{159}$ have noted that requiring admission of the crime may violate the defendant's fifth amendment protection against compelled self-incrimination. The requirement also conflicts with the statement in Sorrells that pleading not guilty raises the entrapment defense. ${ }^{160}$ The proposed rule allows the defendant to remain silent, rely on the presumption of innocence, and require the government to prove every element of its case against the defendant. Thus, the proposed rule is superior to the rule currently applied in the Third, Sixth, and Seventh Circuits. ${ }^{161}$

The proposed inconsistency rule prohibits a defendant froin affirmatively presenting inconsistent defenses. A contrary rule would impose unjustified costs on society-by impairing the trial's truth-seeking function and promoting perjury, for example-and would not significantly benefit defendants. Permitting a defendant to deny any element of the crime and plead entrapment proinotes perjury because it gives the defendant the benefit of one defense that cannot be true. ${ }^{162}$ Moreover, allowing both defenses may unnecessarily confuse the jury and is likely to adversely affect the defendant's credibility.

Permitting a defendant to argue two defenses that cannot both be true is equivalent to sanctioning perjury by the defendant. For example, in United States v. Henry, ${ }^{163}$ Henry testified that he prescribed drugs for a legitimate reason and thus lacked the requisite criminal intent. If Henry's testimony were true, he could not have been entrapped, because the essence of entrapinent is that the government implants criminal in-

158. See, e.g., United States v. Annese, 631 F.2d 1041, 1047 (Ist Cir. 1980); United States v. Demma, 523 F.2d 981, 986 (9th Cir. 1975).

159. Groot, supra note 157, at 278; Nagle, Inconsistent Defenses in Criminal Cases, 92 MIL. L. REv. 77, 98 (1981); Note, Denial of the Crime and the Availability of the Entrapment Defense in the Federal Courts, 22 B.C.L. REv. 911, 930-31 (1981).

160. Sorrells, 287 U.S. at 452.

161. See supra notes $30-36$ and accompanying text.

162. See Note, supra note 159 , at 931 (allowing assertion of inconsistent defenses gives defendant "license to lie").

The Supreme Court has indicated that the protection of a criminal defendant's constitutional rights does not extend to allowing the defendant to commit perjury. See, e.g., Nix v. Whiteside, 106 S. Ct. 988, 998 (1986) (when an accused proposes to resort to perjury, he takes the risk that counsel will withdraw; withdrawal of counsel in such a situation does not violate the sixth amendment right to counsel); Walder v. United States, 347 U.S. 62, 65 (1954) (holding that illegally obtained evidence can be used to impeach a defendant; allowing defendant to affirmatively resort to perjury cannot be justified).

163. 749 F.2d 203, 206 (Sth Cir. 1984) (en banc). 
tent into the defendant. ${ }^{164}$ Of course, the converse is also true; if Henry was entrapped, his testimony about his intent must be false. Allowing Henry to argue both that he lacked intent and that he was entrapped thus allows him either to commit perjury or to take advantage of a defense that cannot be true.

A criminal defendant has no right to commit perjury or to have the assistance of counsel in the presentation of perjury. ${ }^{165}$ An attorney is ethically obligated to refuse to present false evidence. ${ }^{166}$ If the attorney learns that his chent committed perjury after the fact, the attorney may be required to inform the court that the evidence was false. ${ }^{167}$ These ethical obhigations prohibit a defense attorney from assisting his client in asserting imconsistent defenses when to do so would be tantanount to aiding perjury.

Nor does a defense counsel's refusal to allow the client to present false testimony violate the client's right to effective assistance of counsel. 168 The question of how far a criminal defense attorney can go in preventing or disclosing chient perjury has been the subject of a great deal of controversy. ${ }^{169}$ A recent Supreme Court case, Nix v. Whiteside, ${ }^{170}$ dealt directly with this question. Whiteside's counsel, Robinson, learned before trial that his client plamed to testify falsely. ${ }^{171}$ Robinson warned Whiteside against committing perjury, advising Whiteside that if he com-

164. See, e.g., Sorrells, 287 U.S. at 442.

165. Nix v. Whiteside, 106 S. Ct. 988,998 (1986).

166. See Model Code of Professional Responsibility DR 7-102(A)(4), (7) (1981); Model Rules of Professional Conduct Rules 1.2(d), 3.3(a)(4) (1983).

167. See Model Code of Professional ResponsibiLity DR 7-102(B)(1) (1981) (attorney must inform court if client fails to rectify perjury); MODEL RULES OF PROFESSIONAL CONDUCT Rule 3.3 comment 11 (1983) (attorney must inform court if withdrawal is impossible or will not remedy the situation). The District of Columbia Bar, however, has proposed a new code of ethics that would allow criminal defense attorneys to let their clients lie on the stand if the lawyer is unable to dissuade the client from lying or to withdraw from the case without seriously harming the client. See D.C. Bar Wants a New Code of Ethics, Wash. Post, Dec. 1, 1986, at D2, col. 1.

168. Nix, $106 \mathrm{~S}$. Ct. at $998-99$.

169. See, e.g., Model Rules of Professional Conduct Rule 3.3 comment 7 (1983); Appel \& McGrane, Nix v. Whiteside: Client Perjury and the Criminal Justice System: The State's Position, 23 AM. CRim. L. Rev. 19 (1985); Grady, Nix v. Whiteside: Client Perjury and the Criminal Justice System: The Defendant's Position, 23 Am. Crim. L. Rev. 1 (1985); Rieger, Clieut Porjury: A Proposed Resolution of the Constitutional and Ethical Issues, 70 MiNN. L. REv. 121 (1985); Wolfram, Client Perjury: The Kutak Commission and the Association of Trial Lawyers, Lying Clients and the Adversary Systern, 1980 AM. B. Found. REs. J. 964.

170. 106 S. Ct. 988 (1986).

171. Whiteside was accused of murder but claimed he had acted in self-defense. Id. at 991. Whiteside had consistently stated to his attorney, Robinson, that he had not actually seen a gun, but was convinced that the victim had a gun in his hand. Id. A week before trial, however, he told his attorneys that he had seen something "metallic" in the victim's hand. Id. When questioned further about this, Whiteside responded, "If 1 don't say 1 saw a gun 1 'm dead." Id. This was the basis for Robinson's conclusion that Whiteside intended to commit perjury. 
mitted perjury, it would be Robinson's duty to inform the court. ${ }^{172}$ In addition, Robinson said he would seek to withdraw from the case if Whiteside insisted on committing perjury. ${ }^{173}$ In his habeas corpus petition, Whiteside claimed that Robinson's actions constituted a denial of effective assistance of counsel. ${ }^{174}$

The Supreme Court held that Whiteside's sixth amendment rights had not been violated. ${ }^{175}$ The Court could discern "no failure to adhere to reasonable professional standards that would in any sense make out a deprivation of the Sixth Amendment right to counsel."176 The Court noted that "at most [Whiteside] was denied . . . the assistance of counsel in the presentation of false testimony."177 Although the Court stopped short of "constitutionaliz[ing]" any ethical standards, ${ }^{178}$ the majority opinion clearly approved of these standards. ${ }^{179}$ After Nix it is hard to imagine a situation in which a defense attorney who complied with the ethical rules concerning chent perjury would be found to have failed to provide effective assistance of counsel.

The Nix Court concluded that the criminal defendant's right to have counsel present all appropriate defenses does not extend to the presentation of false testimony. ${ }^{180}$ The same rationale applies to the presentation of inconsistent defenses and justifies prohibiting a criminal defendant from affirmatively presenting inconsistent defenses.

The problem of perjury is not umique to criminal trials. Thus, in itself, the possibility that perjury will occur does not seem to justify prohibiting inconsistent defenses in criminal cases while allowing thein in civil cases. Closer analysis of the perjury problem, however, suggests that prohibition of inconsistent defenses is, in fact, justified.

First, analysis of Federal Rule of Civil Procedure 8(e)(2), ${ }^{181}$ which allows inconsistent positions in civil cases, indicates that the rule is not meant to sanction perjury. Rule $8(\mathrm{e})(2)$ is a rule of pleading; it allows a party who is in doubt as to what the evidence will show to advance more than one theory as grounds for relief. ${ }^{182}$ Inconsistent pleadings are, how-

172. Id. at 992.

173. Id.

174. Id.

175. Id. at 997.

176. Id.

177. Id. at 998 .

178. Id. at 994. But see id. at 1006 (Blackmun, J., concurring in the judgment) ("I . . a am troubled by the Court's implicit adoption of a set of standards of professional responsibility for attorneys in state criminal proceedings.").

179. Id. at $994-97$.

180. Id. at 998.

181. Fin. R. Civ. P. 8(e)(2).

182. See Banco Continental v. Curtiss Nat'l Bank, 406 F.2d 510, 513 (5th Cir. 1969). 
ever, subject to the requirements of honesty in pleading. ${ }^{183}$ The signature of the party's attorney on the pleading certifies "that he has read the pleading [and] that to the best of his knowledge, information, and belief formed after reasonable inquiry it is well grounded in fact." 184 Thus, nothing in Rule 8(e)(2) suggests that civil litigants may commit perjury by testifying that each of two mutually exclusive positions is true.

Nor have courts applied Rule 8(e)(2) so as to permit perjury. Under the Rule, courts have allowed civil hitigants to rely on inconsistent legal theories as grounds for relief. ${ }^{185}$ For example, in a suit to enforce a contract, the defendant might argue both that no contract was ever formed and that if a contract was formed, a clause in that contract excuses performance by the defendant. ${ }^{186}$ Although these two positions cannot both be true, under the civil rule the litigant who is in doubt as to what the facts will show is permitted to assert both and let the judge or jury decide whether either defense is valid under the applicable law. The inconsistency here is between legal conclusions (is the defendant excused from performance because no contract was formed? If not, does a clause of the contract excuse defendant's performance?), not between statements of fact. Allowing inconsistent pleading of this kind does not sanction perjury.

Thus, analysis of Rule 8(e)(2) and the cases interpreting it does not indicate that inconsistency of positions rising to the level of perjury should be permitted. Allowing a civil party to plead a defense based on the contract while also denying the existence of the contract is very different from allowing a criminal defendant to say, "I wasn't there, but if I was, they entrapped me." The fact that Rule 8(e)(2) authorizes the former does not suggest that courts should allow the latter.

There is also greater concern about perjury in criminal than in civil cases. A comparison of the discovery provisions in federal civil and criminal proceedings demonstrates this concern. Under the Federal Rules of Civil Procedure, a civil litigant has broad access to his oppo-

183. See 2A J. Moore, Moore's Federal Practice |f 8.33, at 8-230 (2d ed. 1986) (noting that alternative pleadings are subject to requirements of Rule 11 ).

184. FED. R. Civ. P. 11.

185. See, e.g., City of Kingsport v. Steel \& Roof Structure, Inc., 500 F.2d 617, 619 (6th Cir. 1974) (party can plead statute of limitations in bar of claim and alternatively seek indemnification); Fredonia Broadcasting Corp. v. RCA Corp., 481 F.2d 781, 790 (5th Cir. 1973) (corporution culı assert three different theories of relief: fraud, breach of contract, and breach of warranty); Honey $v$. George Hyman Constr. Co., 63 F.R.D. 443, 451 (D.D.C. 1974) (plaintiff can plead both res ipsi loquitur and specific acts of negligence).

186. Cf. Genesco, Inc. v. Joint Council 13, United Shoe Workers of Am.. 341 F.2d 482, 484 (2d Cir. 1965) (union had right to claim that action was barred by arbitration clause whilc reserving right to deny existence of contract). 
nent's documentary evidence and witnesses. ${ }^{187}$ The extensive civil discovery provisions advance the search for truth and eliminate the unfair use of surprise. ${ }^{188}$ In contrast, the Federal Rules of Criminal Procedure limit the defendant's access to the evidence that the prosecution plans to use. Under the federal rules, the defense is entitled to pretrial discovery only of the defendant's own prior statements. ${ }^{189}$ A defendant can obtain prior statements of the prosecution's witnesses after they have testified at trial for purposes of impeachment, ${ }^{190}$ but a defendant has no right to pretrial discovery of such statements. ${ }^{191}$

The decision to limit discovery rights im criminal cases reflects, at least in part, a concern that criminal defendants are more likely than civil litigants to commit perjury. ${ }^{192}$ By refusing to extend fuller discovery to criminal defendants, Congress has indicated that in its view, this risk outweighs the benefits produced by hiberal discovery rules: elimination of the use of surprise tactics and more complete exposure of relevant facts.

Congress not only treats civil and criminal discovery differently but also treats the use of inconsistent defenses differently. Congress specifically provided that a civil hitigant can present inconsistent defenses in civil trials. ${ }^{193}$ Congress's failure to enact a corresponding rule for criminal proceedings may indicate that Congress intended to deny criminal defendants the opportunity to raise imconsistent defenses. ${ }^{194}$ The difference in discovery provisions im civil and criminal proceedings buttresses that conclusion; the same consideration-preventing perjury-that led Congress to limit criminal discovery apphies even more strongly to the issue of inconsistent defenses. The greater concern about perjury in criminal cases justifies prohibiting presentation of inconsistent defenses in criminal proceedings, even though inconsistent defenses are allowed in civil cases.

187. See FED. R. Civ. P. 26-37.

188. See J. UNDerwood, A Guide to Federal D1SCovery Rules 3 (2d ed. 1985).

189. Fed. R. CRIM. P. 16(a)(1)(A).

190. 18 U.S.C. $\S 3500$ (b) (1982).

191. Fed. R. CR1M. P. 16(a)(2).

192. See, e.g., United States v. Persico, 621 F. Supp. 842, 868 (S.D.N.Y. 1985) (criminal discovery is not comparable to civil discovery because of greater danger of perjury). See generally W. LaFave \& J. IsRael, Criminal Procedure $§ 19.3$, at 727-28 (1985) (discussing argument that criminal discovery should be limited because criminal defendant has more at stake than does civil litigant and therefore has greater incentive for perjury).

193. See Fed. R. CIV. P. 8(e)(2).

194. Courts commonly assume that when Congress makes specific provisions in one part a a statutory scheme but not in another, the omission was intentional. See, e.g.. Touche Ross \& Co. v. Redington, 442 U.S. 560, 571-72 (1979) (justifying decision that no implied private right of action exists under section 17(a) of the Securities Exchange Act by noting that other sections of the Act granted express private rights of action). 
Another reason for prohibiting defendants from denying the crime and arguing entrapment is that such inconsistent defenses may confuse the jury. Even with the clearest instructions from the court, a jury is likely to be bewildered by a defendant who swears to one thing and argues another. ${ }^{195}$ Confusing the jury will not necessarily benefit the defendant, and it may actually harm him. In any event, confusing the jury will not promote the truth-seeking function of the trial. Although jury confusion is also likely to occur when inconsistent positions are taken in a civil case, the court can use a special verdict in a civil trial to minimize confusion. ${ }^{196}$ The device of a special verdict, however, is generally unavailable in a criminal trial. ${ }^{197}$

A related problem is the adverse effect on a defendant's credibility that is likely to result when a defendant presents conflicting defenses. The court in United States v. Demma noted that "[i]nconsistent testimony by the defendant seriously impairs and potentially destroys his credibility."198 Nonetheless, the court held that the defendant was entitled to take that chance. ${ }^{199}$ Again, this concern is equally applicable to civil cases. Although the harm to the defendant's credibility may not independently justify the inconsistency rule, it at least suggests that prohibiting a defendant from arguing inconsistent defenses is unlikely to have a detrimental effect on the defendant's case.

Some courts ${ }^{200}$ and commentators ${ }^{201}$ advance public policy arguments in favor of allowing a defendant who denies the crime to argue entrapment. The arguments would be persuasive if the primary purpose of the entrapment defense was to deter police instigation of criminal activity. ${ }^{202}$ Allowing defendants to argue entrapinent whenever there is ev-

195. See Eastman v. United States, 212 F.2d 320, 322 (9th Cir. 1954), overruled by United States v. Demma, 523 F.2d 981 (9th Cir. 1975).

196. See FED. R. Crv. P. 49(a).

197. See, e.g., United States v. Griffin, 705 F.2d 434, 437 (11th Cir. 1983) ("Special verdicts in criminal jury trials are generally disfavored." (quoting United States v. Shelton, 588 F.2d 1242, 1251 (9th Cir. 1978), cert. denied, 442 U.S. 909 (1979))).

198. Demma, 523 F.2d at 985.

199. Id.

200. See, id., at 985 (function of entrapment defense is to safeguard integrity of the law enforccment process). The Demma court relied on Justice Roberts's partial dissent in Sorrells. See id. at 983 n.1. The Sorrells majority, however, implicitly rejected this public policy justification for the entrapment defense, and relied instead on a legislative intent rationale for entrapment. Sorralls, 287 U.S. at 448-49. See supra note 137 and accompanying text.

201. See Nagle, supra note 159, at 125 (inconsistency rule allows police misconduct to go unchallenged); Note, The Assertion of Inconsistent Defenses in Entrapment Cases, 56 lown L. R1:v. 686, 695 (1971) (basic purpose of entrapment defense is to deter wrongful police conduct).

202. An entrapment rule formulated to deter police misconduct would, of course, focus on the methods employed by the government rather than the predisposition of the accused. Sce Sliermun $v$. United States, 356 U.S. 369, 382 (1958) (Frankfurter, J., concurring) (focus should be on wlietlier government conduct falls below proper standards). 
idence of government inducement, regardless of whether the defendant denies the crime, would deter police misconduct. The entrapment defense, however, is not primarily a deterrence measure. ${ }^{203}$ It exists not to monitor police behavior but to protect nonpredisposed defendants from government inducement. ${ }^{204}$ Thus, allowing inconsistent defenses is not necessary to accomplish the purpose of the entrapment defense.

Furthermore, the subjective nature of the entrapment defense does not suggest that it should be available to a federal criminal defendant who denies the crime. The Supreme Court's subjective formulation of entrapment does not focus on the degree of police involvement. Rather, it focuses on the predisposition and intent of the accused. ${ }^{205}$ A defendant who has not committed a criminal act with the requisite criminal intent cannot have been entrapped under federal law. ${ }^{206}$ In contrast, states that have adopted an objective test for entrapment allow a defendant to deny the crime and plead entrapment; ${ }^{207}$ under an objective test, there is no

203. The Supreme Court has indicated that the purpose of the defense is not to prevent "overzealous law enforcement." United States v. Russell, 411 U.S. 423, 435 (1973).

204. As the Supreme Court has stated:

[E]ntrapment is a relatively limited defense. It is rooted, not in any authority of the Judicial Branch to dismiss prosecutions for what it feels to have been 'overzealous law enforcement,' but instead in the notion that Congress could not have intended criminal punishment for a defendant who has committed all the elements of a proscribed offense but was induced to commit them by the Government.

Id. at 435 .

205. Sorrells, 287 U.S. at 451. Professor Groot has argued that "[w]henever a criminal defendant has been entrapped, he has been entrapped into doing an act." Groot, supra note 157, at 265. Groot contends that entrapment is the inducement of prohibited activity, regardless of whether criminal intent is also created. Id. He concludes that denial of the intent element of the crime thus is not inconsistent with a claim of entrapment. Id. at 268. This argument ignores the weight of Supreme Court authority holding that entrapment occurs when government agents implant criminal intent.

206. By definition, entrapment is the implantation of criminal intent into the mind of a nonpredisposed defendant. See Russell, 411 U.S. at 436 ("It is only when the Government's deception actually implants the criminal design in the mind of the defendant that the defense of entrapment comes into play."); Sorrells, 287 U.S. at 442 (entrapment occurs when government implants criminal design in the mind of an innocent person in order to prosecute). The Sorrells Court reversed the decision of the court below, which had held that the entrapment defense could be maintained only where, beeause of government induccment, "the accused is placed in the attitude of having committed a crime which he did not intend to commit, or where, by reason of the consent implied in the inducement, no crime has in fact been committed." Id. See also Henderson v. United States, 237 F.2d 169, 172-73 (5th Cir. 1956) ("If the evidence fails to prove by the required standard that the defendant committed the act charged or had the requisite criminal intent, then, of course, the defense of entrapment is unnecessary.").

207. See, e.g., People v. D'Angelo, 401 Mich. 167, 178, 257 N.w.2d 655, 660 (1977) (objective test for entrapment does not consider defendant's predisposition but focuses instead on activity of government agents; admission of the crime not required to raise entrapment); State v. Taylor, 599 P.2d 496, 500 (Utah 1979) (entrapment defense available even though actor denies commission of the crime). For a discussion of the objective and subjective tests for entrapment and a list of states that have adopted the objective approach, see supra notes 20-21 and accompanying text. 
inconsistency in denying the crime and arguing that the behavior of government agents constituted entrapment. By adhering to the subjective test for entrapment, the Supreme Court has indicated that denial of the crime and a plea of entrapment are inconsistent, not alternative, defenses. ${ }^{208}$

Other commentators suggest that the inconsistency rule impermissibly forces a defendant to choose between pleading not guilty and pleading entrapment. ${ }^{209}$ The commentators advancing this argument erroneously rely on Simmons v. United States. 210 In Simmons, the Supreme Court held that a defendant could not be compelled to forgo his fifth amendment protection against compelled self-incrimination in order to assert a fourth amendment claim. ${ }^{211}$ Simmons thus dealt with a choice between two constitutional rights. The entrapment defense, however, is not founded on constitutional concerns. ${ }^{212}$ In fact, the Supreme Court expressly rejected the suggestion that the entrapment defense should be interpreted as a protection of fourth and fifth amendment interests. ${ }^{213}$ Thus, Simmons does not prohibit forcing a defendant to choose between denying the crime and raising entrapment.

Finally, the existence of a due process defense as an alternative to entrapment ensures that the proposed inconsistency rule will protect the defendant's constitutional rights. ${ }^{214}$ A due process defense is not inconsistent with demial of the crime. The defendant whose constitutional rights have been violated by government activity does not have to choose between denying the crime and objecting to the behavior of government agents. Thus, it is not necessary to allow the defendant who denies the crime to plead entrapment in order to ensure either protection of the defendant's constitutional rights or deterrence of egregious government overreaching. The availability of the due process defense sufficiently achieves both those goals.

208. The subjective formulation of the entrapment defense assumes an accused "has committed all the elements of a proscribed offense." Russell, 411 U.S. at 435 . Thus, it is impossible for entrapment to have occurred where any element of the crime is absent.

209. See Groot, supra note 157, at 273-74; Note, Pleading the Entrapment Defense: The Propriety of Inconsistency, 28 N.Y.L. ScH. L. REV. 1025, 1070-72 (1984).

210. 390 U.S. 377 (1968).

211. Id. at 393-94.

212. Russell, 411 U.S. at 433 (entrapment defense "is not of a constitutional dimension").

213. See id. at 430-31 (rejecting defendant's argument that fourth and fifth amendment concerns should be considered in entrapment analysis).

214. For a discussion of the due process defense, see supra note 22 and accompanying text. 


\section{CONCLUSION}

Significant disagreement currently exists among the federal courts of appeals on the issue whether the entrapment defense should be available to a defendant who does not wish to concede commission of the crime. This disagreement results in widely varying treatment of the issue: some jurisdictions require that a defendant affirmatively admit the crime charged in order to rely on the entrapment defense, while other jursidictions allow a defendant to deny all elements of the crime and plead entrapment. The courts' discussions of this issue reveal confusion about the nature of the entrapment defense and about the appropriateness of inconsistent defenses in crimmal cases. In the absence of guidance from Congress or the Supreme Court, it is unlikely that the controversy will be resolved.

This note advances the justifications for prohibiting a defendant from both denying the crime and pleading entrapment. Such a prohibition is essential to the truth-seeking function of the criminal trial and to deterring the commission of perjury by criminal defendants. The proposed version of the inconsistency rule fully protects a defendant's right to rely on the presumption of innocence and requires the government to prove every element of the case against the defendant. It simply denies the defendant the opportunity to present two defenses that cannot both be true.

Karis A. Hastings 